\title{
Isolation, characterization, and resistance profile of Salmonella spp. from chicken cuts
}

\author{
[Isolamento, caracterização e perfil de resistência de Salmonella spp., provenientes de cortes de frango] \\ A.C.P. Silva ${ }^{1}$ (D) T.P. Morais ${ }^{2}$ (iD), K.B.P.B. Casaril $^{3}$ (iD \\ ${ }^{1}$ Graduate, Universidade Estadual do Oeste do Paraná, Centro de Ciências da Saúde, Francisco Beltrão, PR, Brasil \\ ${ }^{2}$ Undergraduate, Universidade Estadual do Oeste do Paraná, Centro de Ciências da Saúde, Francisco Beltrão, PR, Brasil \\ ${ }^{3}$ Universidade Estadual do Oeste do Paraná, Centro de Ciências da Saúde, Francisco Beltrão, PR, Brasil
}

\begin{abstract}
The present study aimed at isolating and characterizing Salmonella spp. from chicken cuts marketed in Francisco Beltrão, PR, and verify the resistance profile of the isolates against antimicrobials used in human therapy. Samples of chicken cuts $(n=40)$ were purchased from supermarkets and submitted to microbiological analysis for the detection of Salmonella spp. The suspected colonies underwent biochemical testing for the identification of enterobacteria. Four colonies were selected from each sample positive for Salmonella spp., totaling 28 isolates that were tested for antimicrobial sensitivity. Colonies that showed resistance to ceftriaxone were subjected to extended-spectrum beta-lactamases (ESBL). Among the analyzed chicken samples, seven (17.5\%) showed biochemical behavior characteristic of Salmonella spp. Among the 28 isolates, seventeen different resistance profiles were found, of which $46.42 \%(n=13)$ had a multi-resistance profile, and $21.4 \%(\mathrm{n}=6)$ of the isolates had a phenotype for ESBL production. The strains of Salmonella spp. isolated from chicken cuts found in this study showed a high level of resistance to antimicrobials of different classes and of last generations, these data serve as a warning, as they put the human treatment of salmonellosis at risk.
\end{abstract}

Keywords: antimicrobials, microbiota, microorganisms, poultry

A pesquisa objetivou isolar e caracterizar Salmonella spp., a partir de cortes de frangos comercializados na cidade de Francisco Beltrão - PR, bem como verificar o perfil de resistência dos isolados em relação aos antimicrobianos utilizados na terapêutica humana. Amostras de cortes de frango $(n=40)$ foram adquiridas em supermercados e submetidas à análise microbiológica para detecção de Salmonella spp. As colônias suspeitas foram submetidas a provas bioquímicas para identificação de enterobactérias. Quatro colônias foram selecionadas de cada amostra positiva para Salmonella spp., totalizando 28 isolados, que foram testadas quanto à sensibilidade a antimicrobianos. As colônias que apresentaram resistência à ceftriaxona foram submetidas à pesquisa de betalactamases de espectro estendido (ESBL). Das amostras de frango analisadas, sete (17,5\%) apresentaram comportamento bioquímico característico de Salmonella spp. Entre os 28 isolados, foram encontrados 17 perfis diferentes de resistência, tendo 46,42\% ( $n=13)$ apresentado perfil de multirresistência e $21,4 \%(n=6)$ apresentado fenótipo para produção de ESBL. As cepas de Salmonella spp. isoladas de cortes de frango, encontradas neste estudo, apresentaram alto índice de resistência a antimicrobianos de diferentes classes e de últimas gerações. Esses dados servem de alerta, uma vez que coloca em risco o tratamento da salmonelose humana.

Palavras-chave: antimicrobianos, microbiota, microrganismos, avicultura

\section{INTRODUCTION}

Chicken meat is widely consumed by Brazilians since it is considered a healthy, nutritious food, with high protein content. However, this food constitutes a vehicle for pathogenic microorganisms and can cause infections in the consumer population (Welker et al., 2010).

Maintenance of the health of chickens is essential to guarantee the quality of the food that reaches the consumer's table. However, the integrated production system and the innumerable processes

Corresponding author: ana_carooll@hotmail.com

Submitted: November 27, 2020. Accepted: May 19, 2021. 
that the food undergoes until it reaches the consumer contribute to the birds' poor health, thus increasing the risk of contamination (Welker et al., 2010; Zagonel et al., 2017).

Among the microorganisms that can cause diseases in humans, the one of greatest clinical importance is the bacterium Salmonella spp. Despite all technological development and the adoption of hygiene measures by breeders and poultry industries, infections by Salmonella spp. are the most common foodborne diseases worldwide, with most serotypes of the genus being pathogenic to humans. Research has revealed the presence of this bacterium in at least one-third of the broiler samples analyzed (Yamaguchi et al., 2013; Silva and Menão, 2016; Zagonel et al., 2017; Montezani et al., 2018).

For years, antimicrobial agents have been used on a large scale in the production of chickens for therapeutic, prophylactic purposes and as growth promoters. The long-term use of antimicrobial agents in farm animals exerts selective pressure on bacteria, contributing to the development of resistance. Since these animals are intended for human consumption, it is possible that these microorganisms, as well as their resistance genes, may be incorporated into the human microbiota through direct contact with the bird or the ingestion of food or water contaminated with the bacteria (Chantziaras et al., 2014; Lai et al., 2014).

In this context, the present study aimed at isolating and characterizing Salmonella spp. from chicken cuts marketed in Francisco Beltrão - PR and verify the resistance profile of the isolates against antimicrobials used in human therapy.

\section{MATERIAL AND METHODS}

From April to August 2019, samples of chicken meat $(n=40)$ were purchased in supermarkets in Francisco Beltrão - PR. The samples consisted of chilled chicken cuts $(n=24)$, including thighs and drumsticks $(n=15)$, wing drumette $(n=7)$, and breast fillet $(\mathrm{n}=2)$; and frozen chicken cuts $(\mathrm{n}=16)$, including thighs and drumsticks $(\mathrm{n}=13)$, and breast fillet $(n=3)$. The samples were obtained under conventional packaging and commercial conditions (Table 1).
The investigation of Salmonella spp. was carried out according to Brasil (2003) and followed the methodologies recommended by Silva et al. (2010). Suspicious colonies were screened by biochemical testing using a kit for the identification of enterobacteria (NEWPROV), which includes biochemical tests such as deamination of L-tryptophan, production of $\mathrm{H} 2 \mathrm{~S}$, glucose fermentation, gas production, decarboxylation of lysine and ornithine, indole production, motility, use of citrate as a carbon source, and rhamnose fermentation.

Four colonies were selected from each sample that exhibited colonies with biochemical behavior of Salmonella spp., totaling 28 isolates. The samples were subjected to rapid slide agglutination test using polyvalent flagellar serum and were sent to the AQUACEN laboratory of the Veterinary School of the Federal University of Minas Gerais (UFMG) for confirmation of the Salmonella genus using the MALDI -TOF methodology (Benagli et al., 2011).

The sensitivity test to antimicrobials was conducted using the agar diffusion method, according to recommendations of the Clinical and Laboratory Standards Institute (Performance..., 2005). The tested antimicrobial agents included ampicillin $(10 \mu \mathrm{g})$, amoxicillin+clavulanic acid $(20 / 10 \mu \mathrm{g})$, cephalothin $(30 \mu \mathrm{g})$, cephalexin $(30 \mu \mathrm{g})$, nalidixic acid $(30 \mu \mathrm{g})$, ciprofloxacin $(5 \mu \mathrm{g})$, azithromycin $(15 \mu \mathrm{g})$, gentamicin $(10 \mu \mathrm{g})$, sulphazotrin $(25 \mu \mathrm{g})$, meropenem $(10 \mu \mathrm{g})$, nitrofurantoin $(300 \mu \mathrm{g})$, imipenem $(10 \mu \mathrm{g})$, ceftriaxone $(30 \mu \mathrm{g})$, and cefepime $(30 \mu \mathrm{g})$. Reference strains of the American Type Culture Collection were used, namely: Escherichia coli ATCC 25922, Staphylococcus aureus ATCC 25923 (provided by the Microbiology Laboratory of the Regional Hospital of Southwest Paraná), and Salmonella Typhimurium ATCC 14028 (supplied by the Oswaldo Cruz Institute). The results were read and interpreted according to CLSI (Performance..., 2005) standards.

Multidrug resistance was defined as resistance to three or more classes of antimicrobials and isolates with resistance to third generation cephalosporins (ceftriaxone) were subjected to phenotypic evaluation for the production of ESBL, performed using the disc approximation technique, according to CLSI standards (Performance..., 2007). For this study, a 
descriptive statistical analysis of the antimicrobial resistance and sensitivity profile was performed, calculating the absolute and relative frequency.

\section{RESULTS AND DISCUSSION}

Among the total samples analyzed $(n=40)$, seven lots exhibited colonies with biochemical behavior suggestive of the genus Salmonella spp. (17.5\%), five of which were from chilled samples and two from frozen samples, including cuts of thigh and drumstick and wing drumette, as described in Table 1. All isolates submitted to serology and referred for identification by MALDI-TOF were confirmed for the Salmonella genus.

Table 1. Number of samples analyzed and positive for Salmonella spp. isolated from chicken cuts marketed in Francisco Beltrão - PR, according to cut and marketing conditions

\begin{tabular}{lccc}
\hline Cuts & Marketing condition & Total samples analyzed & $\begin{array}{c}\text { Total positive } \\
\text { samples }\end{array}$ \\
\hline Wing drumette & Chilled & $\mathrm{N}=7$ & $\mathrm{~N}=1$ \\
Thigh and drumstick & Frozen & $\mathrm{N}=13$ & $\mathrm{~N}=2$ \\
Thigh and drumstick & Chilled & $\mathrm{N}=15$ & $\mathrm{~N}=4$ \\
Breast fillet & Frozen & $\mathrm{N}=3$ & $\mathrm{~N}=0$ \\
Breast fillet & Chilled & $\mathrm{N}=2$ & $\mathrm{~N}=0$ \\
\hline
\end{tabular}

$\mathrm{N}=$ Number of samples

The frequency of $17.5 \%$ positivity for Salmonella spp. in the lots analyzed in the present survey was similar to other studies found in the literature. Cardoso et al. (2015) verified a $14.6 \%$ presence of Salmonella spp. in chicken samples in São Paulo state between 2000 and 2010. However, the frequency of batches destined for commercialization contaminated by Salmonella spp. is quite variable. In a study by Zagonel et al. (2017), the presence of this bacterium was found in $100 \%$ of chilled chicken meat samples sold in the Alto do Vale do Peixe region in Santa Catarina. Meanwhile, Trainotti et al. (2013), when analyzing 50 samples of chicken meat, found no serotype of Salmonella spp., with all samples meeting the standard of absence of bacteria in $25 \mathrm{~g}$ of the analyzed product.

It is worth mentioning that, in the Brazilian trade, chicken meat can be found frozen or chilled. These forms of storage are not able to destroy bacterial cells of Salmonella spp., however, a reduction in viable cells is expected in freezing. (D'aoust; Maurer, 2007). In the present study, of the seven samples positive for Salmonella spp, five were marketed in the chilled form and only two in the frozen form. Other studies have also shown a greater number of positive samples for Salmonella spp. in chilled chicken samples. In the study by Almeida et al. (2000), of the 15 frozen chicken cuts analyzed, the presence of bacteria of the genus Salmonella was detected in seven, and in 15 of chilled chicken, 13 positive samples were observed for this pathogen.

It is known that the application of good manufacturing practices and the Hazard Analysis and Critical Control Points (HACCP) assist in controlling the presence of these microorganisms in the production line. According to Yamatogi et al. (2016), the moment of slaughter constitutes the main critical point of contamination of chicken meat. However, some stages that precede slaughter, such as capture and transport, are also crucial considering the contamination and proliferation of pathogenic microorganisms, since they generate a stressful environment for the birds, resulting in the disturbance of intestinal functions and increasing the spread of bacteria in the feces, leading to contamination of the carcass, and spread of the pathogen in the production line.

Regarding the sensitivity profile, no isolate was sensitive to all the tested antimicrobials. The antimicrobial susceptibility test results (Table 1 and Fig. 1) revealed that all isolates analyzed showed sensitivity to meropenem, whereas $100 \%$ were resistant to nalidixic acid, representative of the class of first-generation quinolones. When subjected to ciprofloxacin, a third-generation quinolone, no resistance was observed. The strains showed only intermediate resistance and sensitivity. 
Silva et al.

Table 1. Antimicrobial resistance profile of the isolates selected for the Salmonella spp. antibiogram test from broiler cuts marketed in Francisco Beltrão, PR in 2019

\begin{tabular}{|c|c|c|c|c|c|c|c|c|c|c|c|c|c|c|}
\hline \multirow{2}{*}{$\begin{array}{l}\text { Sample } \\
\text { (CFU) }\end{array}$} & \multicolumn{14}{|c|}{ Antimicrobials } \\
\hline & $\mathrm{Nal}$ & Sut & Amc & Azi & Cip & Gen & Amp & Mer & $\mathrm{Cfl}$ & $\mathrm{Ipm}$ & $\mathrm{Cfe}$ & Nit & Cro & $\mathrm{Cpm}$ \\
\hline $1(1)$ & $\mathrm{R}$ & $\mathrm{S}$ & $\mathrm{S}$ & $\mathrm{R}$ & I & $\mathrm{S}$ & $\mathrm{S}$ & $\mathrm{S}$ & $\mathrm{S}$ & $\mathrm{S}$ & $\mathrm{S}$ & $\mathrm{R}$ & $\mathrm{S}$ & $\mathrm{S}$ \\
\hline $1(2)$ & $\mathrm{R}$ & $S$ & S & $\mathrm{R}$ & I & $S$ & $S$ & S & $\mathrm{S}$ & $\mathrm{S}$ & $\mathrm{S}$ & $\mathrm{R}$ & S & $S$ \\
\hline $1(3)$ & $\mathrm{R}$ & $\mathrm{S}$ & $S$ & $\mathrm{R}$ & I & $S$ & $\mathrm{~S}$ & $S$ & $\mathrm{~S}$ & $\mathrm{~S}$ & $\mathrm{~S}$ & $\mathrm{R}$ & $S$ & $S$ \\
\hline $1(4)$ & $\mathrm{R}$ & $S$ & $S$ & I & $S$ & $S$ & $S$ & $S$ & $S$ & $\mathrm{~S}$ & $\mathrm{~S}$ & $\mathrm{I}$ & $S$ & $S$ \\
\hline $2(1)$ & $\mathrm{R}$ & $\mathrm{S}$ & $\mathrm{R}$ & I & $\mathrm{S}$ & $S$ & $\mathrm{R}$ & $S$ & $\mathrm{R}$ & $\mathrm{S}$ & $\mathrm{R}$ & $\mathrm{S}$ & $\mathrm{R}$ & $S$ \\
\hline $2(2)$ & $\mathrm{R}$ & $S$ & $\mathrm{R}$ & I & $S$ & $S$ & $\mathrm{R}$ & S & $\mathrm{R}$ & $S$ & $\mathrm{R}$ & $S$ & $\mathrm{R}$ & $S$ \\
\hline $2(3)$ & $\mathrm{R}$ & $S$ & $\mathrm{R}$ & I & I & $\mathrm{R}$ & $\mathrm{R}$ & $S$ & $\mathrm{R}$ & $S$ & $\mathrm{R}$ & $\mathrm{S}$ & $\mathrm{R}$ & $S$ \\
\hline $2(4)$ & $\mathrm{R}$ & $\mathrm{S}$ & $\mathrm{R}$ & I & $S$ & $S$ & $\mathrm{R}$ & $S$ & $\mathrm{R}$ & $\mathrm{S}$ & $\mathrm{R}$ & $\mathrm{S}$ & $\mathrm{R}$ & $S$ \\
\hline $3(1)$ & $\mathrm{R}$ & $S$ & $S$ & I & $S$ & $S$ & $S$ & $S$ & $\mathrm{~S}$ & $\mathrm{~S}$ & $S$ & I & $S$ & $S$ \\
\hline $3(2)$ & $\mathrm{R}$ & S & S & $S$ & S & $S$ & $S$ & $S$ & $\mathrm{~S}$ & $\mathrm{~S}$ & $S$ & I & S & $\mathrm{S}$ \\
\hline $3(3)$ & $\mathrm{R}$ & $S$ & $S$ & I & $S$ & $S$ & $S$ & $S$ & $\mathrm{~S}$ & $\mathrm{~S}$ & $S$ & I & $S$ & $S$ \\
\hline $3(4)$ & $\mathrm{R}$ & $\mathrm{S}$ & $S$ & I & $S$ & $S$ & $S$ & $S$ & $\mathrm{~S}$ & $\mathrm{~S}$ & $S$ & I & $S$ & $\mathrm{~S}$ \\
\hline $4(1)$ & $\mathrm{R}$ & $\mathrm{S}$ & $S$ & I & $S$ & $S$ & $S$ & $S$ & $\mathrm{~S}$ & $\mathrm{~S}$ & $\mathrm{~S}$ & I & $S$ & $S$ \\
\hline $4(2)$ & $\mathrm{R}$ & $S$ & S & I & $S$ & $S$ & $S$ & S & $S$ & $S$ & $S$ & $\mathrm{R}$ & S & $\mathrm{S}$ \\
\hline $4(3)$ & $\mathrm{R}$ & $S$ & $S$ & I & $S$ & $S$ & $S$ & $S$ & $\mathrm{~S}$ & $\mathrm{~S}$ & $\mathrm{~S}$ & $\mathrm{R}$ & S & $\mathrm{S}$ \\
\hline 4(4) & $\mathrm{R}$ & $S$ & $S$ & I & $S$ & $S$ & $S$ & $S$ & $\mathrm{~S}$ & $\mathrm{~S}$ & $S$ & $\mathrm{~S}$ & $S$ & $S$ \\
\hline $5(1)$ & $\mathrm{R}$ & $\mathrm{S}$ & $S$ & I & I & $S$ & $S$ & $S$ & $\mathrm{R}$ & $\mathrm{S}$ & $\mathrm{S}$ & $\mathrm{R}$ & $S$ & $S$ \\
\hline $5(2)$ & $\mathrm{R}$ & $S$ & S & $\mathrm{R}$ & I & $S$ & $S$ & S & $\mathrm{S}$ & $S$ & $S$ & $\mathrm{R}$ & S & $S$ \\
\hline $5(3)$ & $\mathrm{R}$ & $\mathrm{S}$ & $\mathrm{S}$ & I & $S$ & $S$ & $S$ & $S$ & $\mathrm{~S}$ & $S$ & $S$ & $\mathrm{R}$ & $S$ & $S$ \\
\hline $5(4)$ & $\mathrm{R}$ & $\mathrm{R}$ & $\mathrm{S}$ & $\mathrm{R}$ & I & $\mathrm{S}$ & $\mathrm{S}$ & $S$ & I & $\mathrm{S}$ & $\mathrm{R}$ & $\mathrm{R}$ & $\mathrm{S}$ & $\mathrm{S}$ \\
\hline $6(1)$ & $\mathrm{R}$ & $\mathrm{S}$ & I & $\mathrm{R}$ & $S$ & $\mathrm{R}$ & $\mathrm{R}$ & $S$ & $\mathrm{R}$ & $\mathrm{S}$ & $\mathrm{R}$ & I & $\mathrm{R}$ & $\mathrm{R}$ \\
\hline $6(2)$ & $\mathrm{R}$ & $S$ & $\mathrm{R}$ & $\mathrm{R}$ & I & $\mathrm{R}$ & $\mathrm{R}$ & S & $\mathrm{R}$ & $S$ & $\mathrm{R}$ & $\mathrm{R}$ & $\mathrm{R}$ & $\mathrm{R}$ \\
\hline $6(3)$ & $\mathrm{R}$ & I & I & I & I & $\mathrm{R}$ & $\mathrm{R}$ & $S$ & $\mathrm{R}$ & $\mathrm{R}$ & $\mathrm{R}$ & $\mathrm{R}$ & $\mathrm{R}$ & $\mathrm{R}$ \\
\hline $6(4)$ & $\mathrm{R}$ & $\mathrm{S}$ & I & I & I & I & $\mathrm{R}$ & $S$ & $\mathrm{R}$ & $\mathrm{S}$ & $\mathrm{R}$ & $\mathrm{R}$ & $\mathrm{R}$ & $\mathrm{R}$ \\
\hline $7(1)$ & $\mathrm{R}$ & $\mathrm{S}$ & $\mathrm{S}$ & I & I & $\mathrm{R}$ & $\mathrm{S}$ & $\mathrm{S}$ & $\mathrm{S}$ & $\mathrm{S}$ & $\mathrm{S}$ & $\mathrm{R}$ & $\mathrm{S}$ & $\mathrm{S}$ \\
\hline $7(2)$ & $\mathrm{R}$ & $\mathrm{S}$ & $\mathrm{S}$ & I & $\mathrm{S}$ & $\mathrm{R}$ & $\mathrm{S}$ & $\mathrm{S}$ & $\mathrm{R}$ & $\mathrm{S}$ & $\mathrm{R}$ & I & $\mathrm{R}$ & $\mathrm{R}$ \\
\hline $7(3)$ & $\mathrm{R}$ & $\mathrm{S}$ & $\mathrm{S}$ & $\mathrm{S}$ & $S$ & $\mathrm{R}$ & $\mathrm{S}$ & $S$ & $\mathrm{~S}$ & $\mathrm{~S}$ & $\mathrm{~S}$ & $S$ & $\mathrm{~S}$ & $\mathrm{~S}$ \\
\hline $7(4)$ & $\mathrm{R}$ & $\mathrm{S}$ & $\mathrm{S}$ & I & $\mathrm{S}$ & $\mathrm{R}$ & $\mathrm{R}$ & $\mathrm{S}$ & $\mathrm{R}$ & $\mathrm{S}$ & $\mathrm{R}$ & $\mathrm{R}$ & $\mathrm{R}$ & $\mathrm{R}$ \\
\hline
\end{tabular}

CFU- Colony Forming Unit.

NAL- Nalidixic Acid, SUT- Sulfazotrim, AMC- Amoxicillin + Clavulanic Acid, AZI- azithromycin, CIPCiprofloxacin, GEN- Gentamicin, AMP- Ampicilin, MER- Meropenem, CFL- Cephalotin, IPM - Imipenem, CFECephalexin, NIT- Nitrofurantoin, CRO- Ceftriaxone, CPM- Cefepime.

R- Resistant, S- Sensitive, I- Intermediate. 


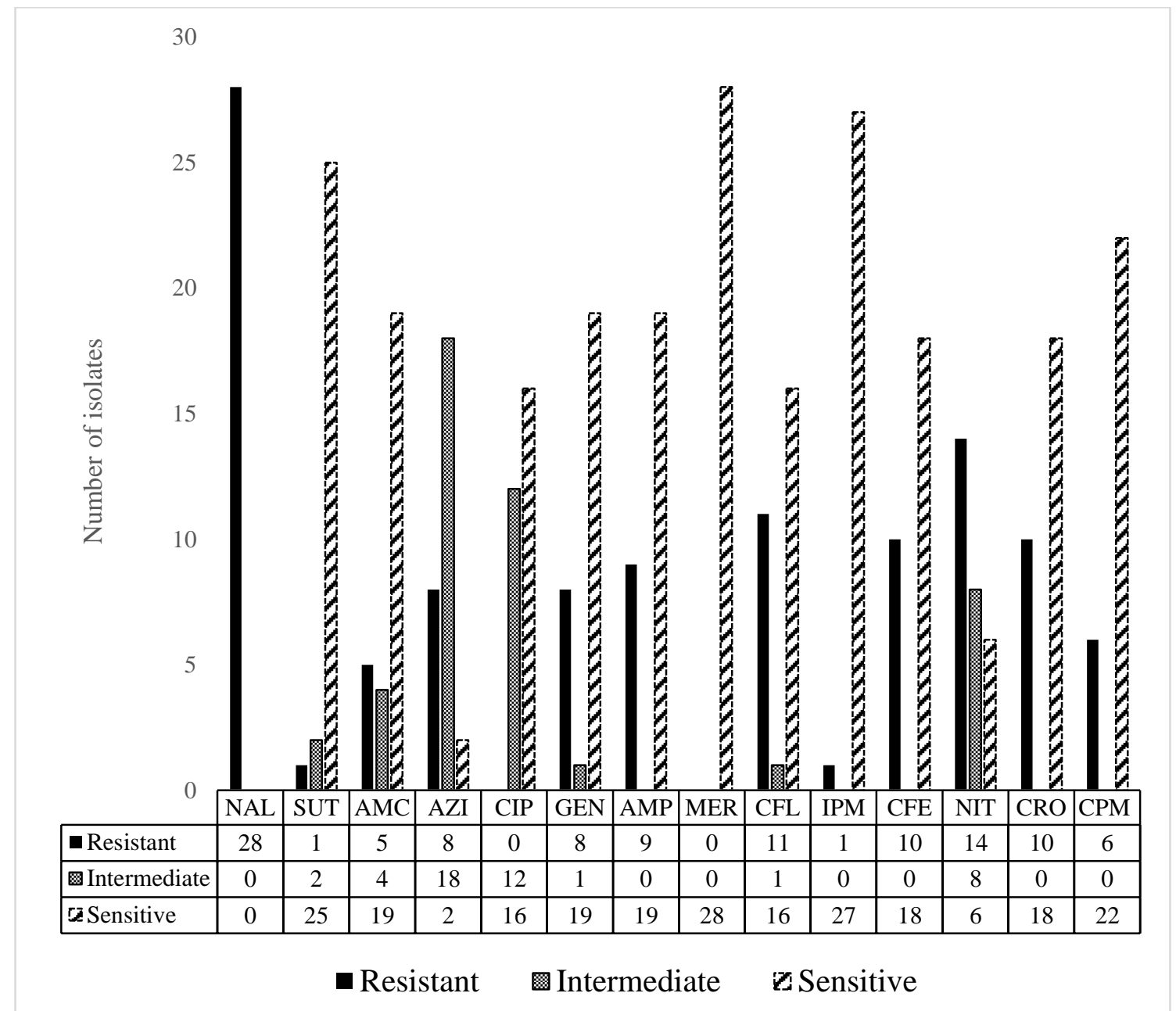

NAL- Nalidixic Acid, SUT- Sulfazotrim, AMC- Amoxicillin + Clavulanic Acid, AZI- azithromycin, CIPCiprofloxacin, GEN- Gentamicin, AMP- Ampicilin, MER- Meropenem, CFL- Cephalotin, IPM - Imipenem, CFECephalexin, NIT- Nitrofurantoin, CRO- Ceftriaxone, CPM- Cefepime.

Figure 1. Number of isolates with intermediate resistance, resistance and sensitivity to antimicrobials tested.

In relation to the other antimicrobial tested, the strains of Salmonella spp. showed resistance to nitrofurantoin $(50 \%)$, cephalothin $(39.3 \%)$, cephalexin (39.3\%), ceftriaxone $(35.7 \%)$, ampicillin (32.1\%), gentamicin $(28.6 \%)$, azithromycin (28.6\%), cefepime (21.4\%), amoxicillin with clavulanate (17.9\%), sulphazotrin (3.6\%), and imipenem (3.6\%).

Considering the total isolated, $42.9 \%(\mathrm{n}=12)$ were resistant to at least one of the beta-lactam agents tested, in which the first-generation cephalosporins, cephalexin and cephalothin, and ampicillin showed the highest percentage of resistance within this class of antimicrobials (resistance percentages of $39.3 \%, 39.3 \%$, and 32.1 , respectively).

The high resistance index found herein was similar to other studies that also reported a rate of $100 \%$ resistance to at least one of the antimicrobials tested in strains of Salmonella spp (Pandini et al., 2015).

Ten isolates (35.7\%) were resistant to third generation cephalosporins (ceftriaxone) and underwent phenotypic analysis regarding ESBL production. Among the ten isolates tested, six revealed this resistance mechanism phenotype, evidenced by halo distortion and the formation of a "phantom zone" in the approach disc test. 
In addition to resistance against third generation cephalosporins, $21.4 \%$ of the tested microorganisms were resistant to cefepime, a fourth-generation cephalosporin, and one isolate (6-5) showed resistance to imipenem, a representative of the carbapenem class.

In this study, 17 different resistance profiles (P1 to P17) were identified, as shown in Table 2. The most frequent profiles were $\mathrm{P} 3$, represented by five of the 28 isolates (17.8\%), characterized by resistance to nalidixic acid, intermediate resistance to azithromycin and nitrofurantoin, and sensitivity to the other tested antimicrobials, and P6, with four isolates (14.2\%) exhibiting resistance to nalidixic acid, azithromycin, and nitrofurantoin, intermediate resistance to ciprofloxacin, and sensitivity to the other tested antimicrobials.

Of the total of isolated, $42.9 \%$ presented a multidrug resistance profile, showing resistance to three or more different classes of antimicrobials, $21.4 \%$ of which exhibited an ESBL production phenotype, evidenced by the approach disc test (Table 2).

Table 2. Resistance profiles and intermediate resistance of 28 isolates of Salmonella spp. from chicken cuts marketed in Francisco Beltrão, PR

\begin{tabular}{|c|c|c|c|c|}
\hline $\begin{array}{l}\text { Resistance } \\
\text { profiles }\end{array}$ & Antimicrobial resistance & Classes $^{1}$ & $\mathrm{ESBL}^{2}$ & $\begin{array}{l}\text { Isolates }^{3} \\
(\%)\end{array}$ \\
\hline P1 & NAL (NIT) & 2 & - & $1(3.5)$ \\
\hline $\mathrm{P} 2$ & NAL, GEN & 2 & - & $1(3.5)$ \\
\hline P3 & NAL (AZI), (NIT) & 3 & - & $5(17.8)$ \\
\hline P4 & NAL (AZI), (CFL) & 3 & - & $1(3.5)$ \\
\hline P5 & NAL, NIT (AZI) & 3 & - & $3(10.7)$ \\
\hline P6 & NAL, AZI, NIT (CIP) & 3 & - & $4(14.2)$ \\
\hline P7 & NAL, GEN, CRO, CPM (AZI), (NIT) & 5 & + & $1(3.5)$ \\
\hline P8 & NAL, AMC, AMP, CFL, CFE, CRO (AZI) & 3 & - & $3(10.7)$ \\
\hline P9 & NAL, CFL, NIT (AZI), (CIP) & 4 & - & $1(3.5)$ \\
\hline P10 & NAL, GEN, NIT (AZI), (CIP) & 4 & - & $1(3.5)$ \\
\hline P11 & $\begin{array}{l}\text { NAL, AMC, GEN, AMP, CFL, CFE, CRO } \\
\text { (AZI), (CIP) }\end{array}$ & 4 & - & $1(3.5)$ \\
\hline $\mathrm{P} 12$ & $\begin{array}{l}\text { NAL, AMP, CFL, CFE, NIT, CRO, CPM } \\
(\text { AMC), (AZI), (CIP), (GEN) }\end{array}$ & 5 & + & $1(3.5)$ \\
\hline P13 & $\begin{array}{l}\text { NAL, AZI, GEN, AMP, CFL, CFE, CRO, } \\
\text { CPM (AMC), (NIT). }\end{array}$ & 5 & + & $1(3.5)$ \\
\hline P14 & $\begin{array}{l}\text { NAL, GEN, AMP, CFL, CFE, NIT, CRO, } \\
\text { CPM (AMC), (AZI) }\end{array}$ & 5 & + & $1(3.5)$ \\
\hline P15 & NAL, SUT, AZI, CFE, NIT (CIP), (CFL) & 5 & - & $1(3.5)$ \\
\hline P16 & $\begin{array}{l}\text { NAL, AMC, AZI, GEN, AMP, CFL, CFE, } \\
\text { NIT, CRO, CPM (CIP) }\end{array}$ & 5 & + & $1(3.5)$ \\
\hline P17 & $\begin{array}{l}\text { NAL, GEN, AMP, IPM, CFL, CFE, NIT, } \\
\text { CRO, CPM (SUT), (AMC), (AZI), (CIP) }\end{array}$ & 6 & + & $1(3.5)$ \\
\hline
\end{tabular}

* Profiles in parentheses: strains with intermediate resistance to antimicrobials.

1 Number of classes of antimicrobials to which the isolates were resistant.

2 ESBL phenotypic research using the disk approximation method.

3 Number of isolates that presented a determined resistance profile.

+ Positive result, - Negative result.

NAL- Nalidixic Acid, SUT- Sulfazotrim, AMC- Amoxicillin + Clavulanic Acid, AZI- azithromycin, CIPCiprofloxacin, GEN- Gentamicin, AMP- Ampicilin, MER- Meropenem, CFL- Cephalotin, IPM - Imipenem, CFECephalexin, NIT- Nitrofurantoin, CRO- Ceftriaxone, CPM- Cefepime. 
Resistance to beta-lactams was found in $42.9 \%$ of the isolates, with resistance to at least one representative of this class. Among the betalactams, cephalosporins showed a higher percentage of resistance, including third- and fourth-generation representatives.

For many years, conventional treatment for Salmonella spp. was performed using a combination of sulfamethoxazole with trimethoprim and a representative of the penicillin group, such as amoxicillin or ampicillin. However, the high resistance that Salmonella strains have shown to penicillin rendered thirdand fourth generation cephalosporins more suitable for the treatment of these infections (Sánchez-Vargas et al., 2011). Therefore, the data found in this study causes concern, since the isolates were also resistant to these drugs.

In the present study, multiresistant isolates were found, that is, resistant to three or more different classes of antimicrobials. Multidrug resistance is a worldwide public health problem. In studies carried out in Spain and Iran, a 100\% frequency of multidrug-resistant Salmonella spp. strains was found present in chicken cuts (Alvarez-Fernández et al., 2012; Fallah et al., 2013). In Turkey, $92.85 \%$ of the Salmonella spp. exhibited multiresistance profiles (Siriken et al., 2015). In Brazil, these data are also high. A study conducted by ANVISA, which monitors the prevalence and the sensitivity profile to antimicrobials against Salmonella spp. and Enterococcus spp. isolated from frozen chicken carcasses, revealed that $76.8 \%$ of the 250 samples of Salmonella spp. analyzed were classified as multiresistant (Brasil, 2012). Later, Lopes et al. (2016) reported that $60 \%$ of Salmonella Typhimurium isolates showed multidrug resistance.

Resistance to several different classes of antimicrobials is a global alert issue, limiting treatment options for these infections, as well as presenting a high potential for dissemination since bacteria have the ability to transfer resistance genes to other pathogenic microorganisms (Iglesias et al., 2017; Fardsanei et al., 2018).

When analyzing the different resistance and multiresistance profiles found in this study, it was observed that resistance to beta-lactams was associated with resistance to drugs in the group of quinolones (NAL) and/or nitrofurans (NIT), aminoglycosides (GEN), and macrolides (AZI). These multidrug-resistance phenotypes in Salmonella spp. have been associated with the presence of plasmids that carry resistance genes to several antimicrobials, such as strains that produce ESBL enzymes, responsible for conferring resistance to beta-lactams, which generally exhibit co-resistance to quinolones and aminoglycosides (Fernandes et al., 2009; Uma et al., 2010). Upon performing phenotypic analysis to detect ESBL, six isolates, corresponding to $21.4 \%$ of the total samples, presented the phenotype of this resistance mechanism.

Only a few drugs belonging to the carbapenem class retain their activity against ESBL-producing enterobacteria (Pitout, 2010). The occurrence of a resistance profile that includes imipenem (P17), found in this study, is probably due to carbapenem usage in Brazil as a therapeutic alternative to fight these infections. These data highlight the need for the rational use of carbapenems in order to prevent the emergence of new multiresistant microorganisms.

A study carried out in Brazil, between 2007 and 2011, with 12,582 strains of Salmonella spp., indicates the exponential growth of isolates with multidrug-resistant profiles, including third generation cephalosporins (Costa et al., 2013). The increasingly high frequency of these multidrug-resistant strains of Salmonella spp. may be related to inappropriate antimicrobial usage in the poultry sector and the spread of antimicrobial resistance genes from one bacterium to another. In order to avoid the spread of resistance, caution and responsibility in antimicrobial use in veterinary and human medicine are necessary, in addition to continuous epidemiological monitoring (Lai et al., 2014).

Knowing the profile of sensitivity and resistance to antimicrobials of Salmonella spp. isolated from food intended for human consumption is extremely imperative since it is an important epidemiological marker and provides data that guide therapy in veterinary and human medicine, both of which use these same antimicrobial agents to treat infections (Brasil, 2012).

It is worth mentioning that optimization by the poultry industries in the production chain and guidance to food handlers regarding hygienicsanitary aspects, combined with the application of 
antimicrobial control as growth promoters and prophylactic agents are vital points to avoid the selection and dissemination of resistance to antimicrobials (Lai et al., 2014).

\section{CONCLUSIONS}

The strains of Salmonella spp. isolated from chicken cuts, found in this study, showed a high level of resistance to antimicrobials of different classes and of last generations. The highest percentage of resistance was obtained for the group of beta-lactams, including the production of ESBL. The presence of Salmonella spp. with a multi-resistance profile was also observed, especially co-resistance among beta-lactams, fluoroquinolones, and aminoglycosides. These data serve as a warning due to the ability to transfer resistance from one bacterium to another, generating high-potential dissemination, which places the human treatment of salmonellosis at risk.

\section{REFERENCES}

ALMEIDA, C.I.; GONÇALVES, P.M.R.; FRANCO; R.M. et al. Isolamento e identificação de Salmonella em carcaças de frango congelados e frescais, através de método rápido. Hig. Aliment., v.14, p.59-62, 2000.

ALVAREZ-FERNÁNDEZ, E.; ALONSOCALLEJA， C.; GARCÍIA-FERNÁNDEZ， C.; CAPITA, R. Prevalence and antimicrobial resistance of Salmonella serotypes isolated from poultry in Spain: comparison between 1993 and 2006. Int. J. Food Microbiol., v.153, p.281-287, 2012.

BENAGLI, C.; ROSSI, V.; DOLINA, M. et al. Matrix-assisted laser desorption ionization-time of flight mass spectrometry for the identification of clinically relevant bacteria. PLoS One, v.6, p.e16424, 2011.

BRASIL. Ministério da Agricultura, Pecuária e Abastecimento. Instrução Normativa ${ }^{\circ} 62$ de 26 de agosto de 2003. Oficializa os métodos analíticos oficiais para análises microbiológicas para controle de produtos de origem animal e água. Diário Oficial da União, Brasília, 18 set. 2003. Disponível em: https://www.defesa.agricultura.sp.gov.br/legislacoe s/instrucao-normativa-sda-62-de-26-082003,665.html. Acessado em: 20 jun. 2019.
BRASIL. Ministério da Saúde. Agência Nacional de Vigilância Sanitária - Anvisa. Relatório do monitoramento da prevalência e do perfil de suscetibilidade aos antimicrobianos em enterococos e salmonelas isolados de carcaças de frango congeladas comercializadas no Brasil. Programa Nacional de Monitoramento da Prevalência e da Resistência Bacteriana em Frango (PREBAF). Brasília, 2012. Disponível em: http://portal.anvisa.gov.br/documents/33916/39548 1/Relat\%C3\%B3rio+Prebaf++Programa+Nacional + de+Monitoramento+da+Preval\%C3\%AAncia+e+ da+Resist\%C3\%AAncia+Bacteriana+em+Frango++2008/04658e9f-7ca6-4e4b-b4fe-0fb7ef54a04e

Acessado em: 29 jun. 2019.

CARDOSO, A.L.S.P.; KANASHIRO, A.M.; STOPPA, G.F.Z. et al. Ocorrência de Salmonella spp. em carcaças de frango provenientes de abatedouros do estado de São Paulo, Brasil, no período de 2000 a 2010. Rev. Cient. Med. Vet., v.24, p.1-12, 2015.

CHANTZIARAS, I.; BOYEN, F.; CALLENS, B.; DEWULF, J. Correlation between veterinary antimicrobial use and antimicrobial resistance in food-producing animals: a report on seven countries. J. Antimicrob. Chemother., v.69, p.827-834, 2014.

COSTA, R.G.; FESTIVO, M.L.; ARAUJO, M.S. et al. Antimicrobial susceptibility and serovars of Salmonella circulating in commercial poultry carcasses and poultry products in Brazil. J. Food Protect., v.76, p.2011-2017, 2013.

D'AOUST, J.Y.; MAURER, J. Salmonella species. In: DOYLE, M.P.; BEUCHAT, L.R. (Eds.). Food microbiology: fundamentals and frontiers. Washington: ASM Press, 2007. 1138p.

FALLAH, S.H.; ASGHARPOUR, F.; NADERIAN, Z.; MOULANA, Z. et al. Isolation and determination of antibiotic resistance patterns in non-typhoid Salmonella spp isolated from chicken. Int. J. Enteric Pathogens, v.1, p.17-21, 2013.

FARDSANEI, F.; DALLALA, M.M.S.; DOURAGHIA. M. et al. Antimicrobial resistance, virulence genes and genetic relatedness of Salmonella enterica serotype Enteritidis isolates recovered from human gastroenteritis in Tehran, Iran. J. Global Antimicrob. Resist., v.12, p.220-226, 2018.

FERNANDES, S.A.; PATERSON, D.L.; GHILARDI-RODRIGUES, A.C. et al. CTX-M-2 producing Salmonella Typhimurium isolated from pediatric patients and poultry in Brazil. Microb. Drug Resist., v.15, p.317-321, 2009. 
IGLESIAS, M.A.; KRONING, I.S.; DECOL, L.T. et al. Occurrence and phenotypic and molecular characterization of Listeria monocytogenes and Salmonella spp. in slaughterhouses in southern Brazil. Food Res. Int., v.100, p.96-101, 2017.

LAI, J.; WU, C.; WU, C. et al. Serotype distribution and antibiotic resistance of Salmonella in foodproducing animals in Shandong province of China, 2009 and 2012. Int. J. Food Microbiol., v.180, p.30-38, 2014.

LOPES, G.V.; MICHAEL, G.B.; CARDOSO, M.; SCHWARZ, S. Antimicrobial resistance and class 1 Integron-associated gene cassetetes in Salmonella enterica serovar Typhimurium isolated from pigs at slaughter and abattoir environment. Vet. Microbiol., v.194, p.84-92, 2016.

MONTEZANI, E.; GIUFFRIDA, R.; ANDRADE, R.A.P.; SILVA, B.L. Isolamento de Salmonella spp. e Staphylococcus aureus em carne de frango e condições dos estabelecimentos comerciais no município de Tupã-SP. Colloquium Vitae, v.9, p.3036,2018

PANDINI, J.A.; PINTO, F.G.S.; MULLER, J.M. Occurrence and antimicrobial resistance profile of Salmonella spp. serotypes isolated from poultry farms in Paraná, Brazil. Arq. Inst. Biol., v.20, p.1-6, 2015 .

PERFORMANCE standards for antimicrobial susceptibility testing. 8.ed. Wayne: CLSI / National Committee for Clinical Laboratory Standards. 2005. 58p. Disponível em: http://www.anvisa.gov.br/ servicosaude/manuais/clsi/clsi_OPASM2-A8.pd>. Acessado em: 21 jul.2019.

PERFORMANCE standards for antimicrobial susceptibility testing; seventeenth informational supplement. CLSI document M100-S17. Wayne, Pennsylvania: CLSI, 2007. Disponível em: https://www.facm.ucl.ac.be/intranet/CLSI/CLSIM100S17-susceptibility-testing-2007-unlocked.pdf. Acessado em: 15 jan. 2020.

PITOUT, J.D. Infections with extended-spectrum beta-lactamase-producing enterobacteriaceae: changing epidemiology and drug treatment choices. Drugs, v.70, p.313-333, 2010.

SÁNCHEZ-VARGAS, F.M.; ABU-EL-HAIJA, M.A.; GÓMEZ-DUARTE， O.G. Salmonella infections: An update on epidemiology, management, and prevention. Travel Med. Infect. Dis., v.154, p.26-29, 2011.
SILVA， K.R.C.; MENÃO, M.C. Avaliação microbiológica de cortes de frangos comercializados na cidade de São Paulo. Atlas Saúde Ambiental, v.3, p.17-23, 2016.

SILVA, N.; JUNQUEIRA, V.C.A.; SILVEIRA, N.F.A. et al. Manual de métodos de análise microbiológica de alimentos e água. 4.ed. São Paulo: Varela, 2010. 624p.

SIRIKEN, B.; TURK, H.; YILDIRIM, T. et al. Prevalence and characterization of Salmonella isolated from chicken meat in turkey. Food. Res. Int., v.80, p.9-16, 2015

TRAINOTTI, A.C.; MORAES, F.F.; BEGOTTI, I.L.; MERLINI, L.S. Ocorrência de Salmonella sp. em cortes de frangos industrialmente processados procedentes de explorações industriais da região noroeste do estado do Paraná - Brasil. Encicl. Biosfera Centro Cient. Conhecer, v.9, p.1964-1970, 2013.

UMA, B.; PRABHAKAR, K.; RAJENDRAN, S.; LAKSHMI SARAYU, Y. Prevalence of extended spectrum beta lactamases in Salmonella species isolated from patients with acute gastroenteritis. Indian J. Gastroenterol., v.29, p.201-204, 2010.

WELKER, C.A.D.; BOTH, J.M.C.; LONGARAY, S.M. et al. Análise microbiológica dos alimentos envolvidos em surtos de doenças transmitidas por alimentos (DTA) ocorridos no estado do Rio Grande do Sul, Brasil. Rev. Bras. Biocienc., v.8, p.44-48, 2010.

YAMAGUCHI, U.M.; MOARAIS, J.F.; FRAUSTO, H.S.G.; SILVERIO, K.I. Qualidade microbiológica de alimentos e de ambientes de trabalho: pesquisa de Salmonella e Listeria. Rev. Agronegócio Meio Ambiente, v.6, p.417-434, 2013.

YAMATOGI, R.S.; OLIVEIRA, H.C.; POSSEBON, F.S. Qualitative and quantitative determination and resistance patterns of Salmonella from poultry carcass. J. Food Protect., v.79, p.950955, 2016.

ZAGONEL, E.F.; ESPINOLA, M.E.; PARIS, V.P.S.; GELINSKI, J.M.L.N. Avaliação presuntiva da qualidade higiênico-sanitária de coxas e sobrecoxas de frango resfriadas obtidas comercialmente. Anuário Pesqui. Extensão Unoesc Videira, v.2, p.e13457, 2017. 